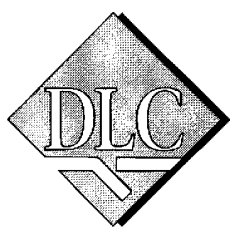

\title{
The Tertiary opening of the North Atlantic: DLC investigations along the east coast of Greenland
}

\author{
Hans Christian Larsen, C. Kent Brooks, John R. Hopper, Trine Dahl- \\ Jensen, Asger K. Pedersen, Troels F. D. Nielsen and field parties
}

Work along the east coast of Greenland in the summer of 1994 represents the initiation of the Danish Lithosphere Centre (DLC) investigations into the magmatic and tectonic evolution accompanying initial break-up of the North Atlantic in this area. As described by Larsen (this report), the aims of DLC are the understanding of the composition and thermal state of the asthenosphere and the deformation of the lithosphere during continental break-up and formation of volcanic rifted margins. Furthermore, the time scale of these events is crucial to any model of break-up.

To meet these aims it is necessary to obtain records of magmatism and tectonic development in space and through time. Previous investigations in East Greenland (Fig. 1) have given sufficient material and information for specific areas, but correlation between these areas is poor and major areas of plateau basalts and dyke swarms have never been investigated in any detail. The field campaigns of 1994 and 1995 and seismic campaigns in 1994 and 1996, together with ODP legs 152 and 163 (planned for September-October 1995) are designed to ensure correlation between magmatic and tectonic developments along $2000 \mathrm{~km}$ of the continental margin; representative samples will be collected of the types of magmas formed and erupted at different stages in the development of, and at variable distances from, the supposed plume centre at Kangerlussuaq $\left(68^{\circ} \mathrm{N}\right)$. In addition DLC has proposed deep continental drilling of the continental margin to gain a clearer picture of the structure at depth and, if possible, to recover dense underplated material believed to exist beneath such margins.

\section{Investigations of the crustal structure offshore South-East Greenland}

Many continental margins show evidence for extremely large volume volcanism at the time of break-up (e.g. Mutter et al., 1988; Coffin \& Eldholm, 1992, 1993). Seismic images from many such volcanic rifted margins show evidence for seaward-dipping reflector sequences (SDRS), which are widely regarded as evidence for large volume, subaerial volcanism during extension (Hinz, 1981). An example from the recently acquired data described below is shown in Fig. 2, and a cartoon illustrating the formation of the structures in Fig. 3. In some cases, volcanic sequences in excess of $6 \mathrm{~km}$ thick and underlain by $10 \mathrm{~km}$ or more of igneous crust have been imaged using seismic reflection and refraction techniques (Hopper et al., 1992 ; Holbrook \& Keleman, 1993). While simple thermal and chemical models of mantle processes can adequately explain the generation of oceanic crustal material (McKenzie $\&$ Bickle, 1988), these volcanic rifted margins have proved to be enigmatic. One of the main goals of the DLC geophysics programme is to study these problems and collect data that will enable us to further constrain and understand the origin and evolution of volcanic rifted margins.

\section{New seismic reflection data}

A major step towards a better understanding of one such margin was taken in August 1994, when DLC collected $1094 \mathrm{~km}$ of deep seismic reflection data offshore SouthEast Greenland (Dahl-Jensen et al., 1994; Fig. 1). The survey, called ICE (Igneous Crustal Extension), was carried out using the M/V GECO Echo, a seismic survey vessel owned and operated by the commercial firm GECO-Prakla. The data was shot using a 48 air-gun, tuned source array with a nominal capacity of $9324 \mathrm{cu}$. in. The source was specifically designed to enhance low frequencies to permit adequate imaging of lower crustal and perhaps even upper mantle structures. In order to facilitate multiple attenuation and velocity filtering, the data were recorded on a $4600 \mathrm{~m}$ streamer with a group interval of $12.5 \mathrm{~m}$, a shotpoint interval of $37.5 \mathrm{~m}$ and a recording time of $14 \mathrm{~s}$.

In addition to imaging and mapping the extent of volcanic sequences of the rifted margin, a further goal of the survey is a study of the Precambrian crust of the margin immediately adjacent to the volcanic sequences. For this purpose, a reflection line was collected parallel to the coast from latitudes $60^{\circ} 30^{\prime}-62^{\circ} 45^{\prime} \mathrm{N}$. In this part of the survey, a $75 \mathrm{~m}$ shotpoint interval and a recording time of $27 \mathrm{~s}$ was used. These shots were also recorded on land by three seismic stations set up along the coast in order to supplement the near vertical reflection imaging with some wideangle refraction information. 


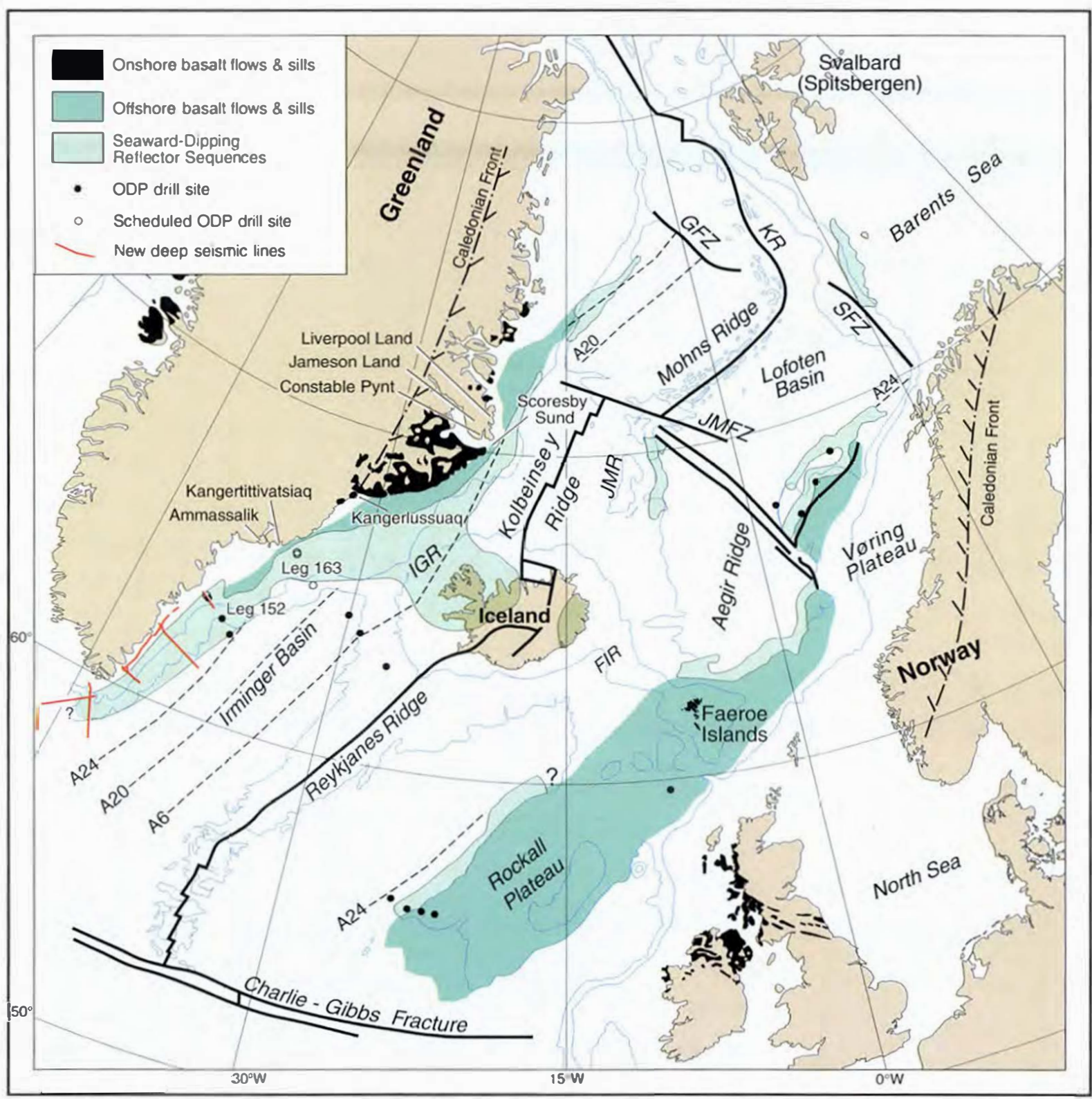

Fig. I: Map of the North Allantic showing the distribution of seaward dipping reflectors as known today. fracture zones (GF\%.. SFZ, JMFZ), ocean floor ridges (KR. JMR). ocean ridges (IGR. FIR) and ocean floor magnetic anomalies. Seismic reflection lines collected 1994 at the south tip of Greenland are indicated together with the ODP Leg 1.52 transect completed 1993 and the ODP Leg 163 iransect planned for 1995

\section{Results}

All of the raw datal are now in-house they are being processed with a newly acyured Sun SPARC workstation using the commercial solitware parkalge ProMAX. Preliminary results based on brute stacks of the daltal show that seaward dipping reflector sequences, and thus large volume volcanism. are found as far south as $58^{\circ} 30^{\circ} \mathrm{N}$, only 75 $\mathrm{km}$ from the former triple junction south of Greenland and c. $1300 \mathrm{~km}$ from the presumed track of the Iceland hotspot alt $68^{\circ} \mathrm{N}$. The new dalta thus confirm the continuous presence of the SIDRS along 1300 km of the South-Fast Greenland margin (as suggested by Larsen \& Jakobsdillir, 1988) and imply that the area alfected by anomalous break-up volcanism had a diameter of $25(0) \mathrm{km}$ or more. (n the Iceland-Greenland Ridge (IGR on Fig. I), the SDRS is very broad and spans most of the Paleogene and possibly also the Neogene, but it rapidly narrows to the south away from the supposed plume track (Larsen \& Jakobsdottir. 1988; Larsen, $199(0)$. At $63^{\circ} \mathrm{N}$ it is largely restricted to the 


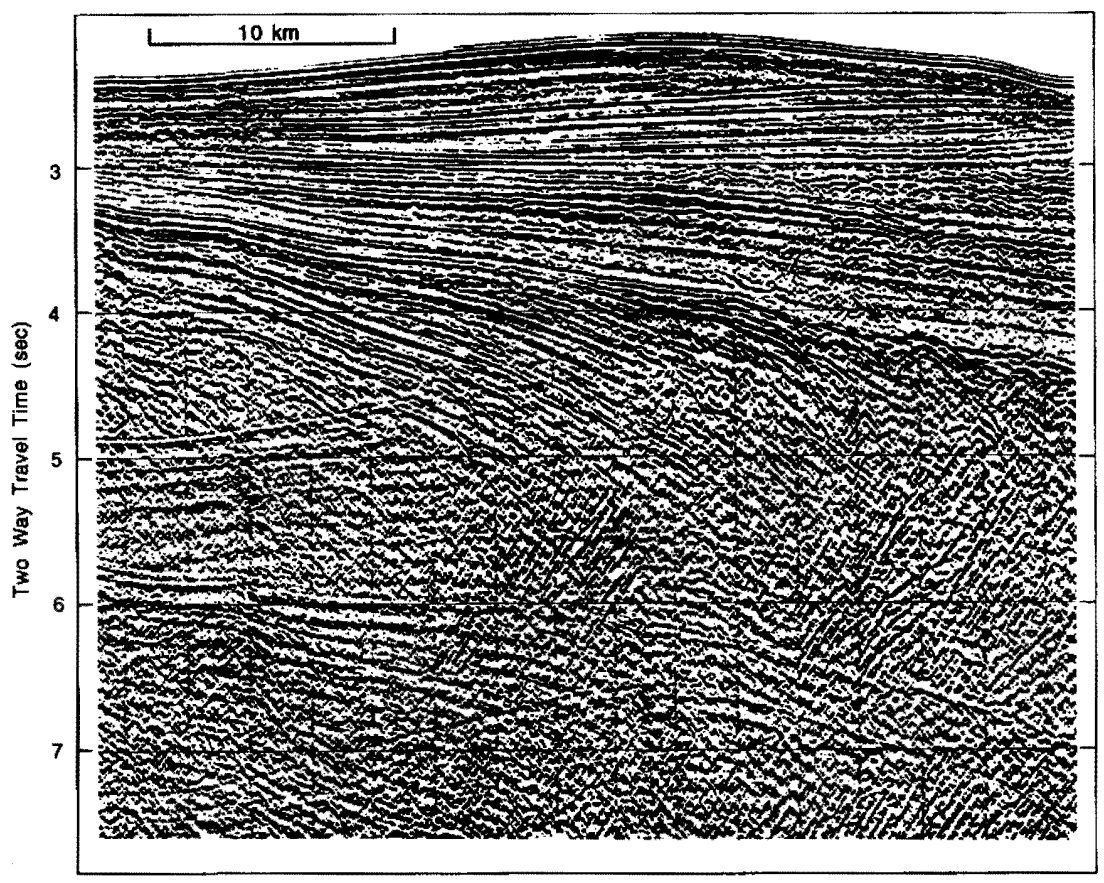

Fig. 2. An example of seaward-dipping reflector sequences interpreted as evidence for large volume magmatism at the time of break-up and the onset of seafloor spreading. This example is a brute stack of Line DLC/94-l from the survey described here. magnetic intervals chrons $24 \mathrm{r}$ and $24 \mathrm{n}$, and in the far south seems to terminate well before magnetic chron $24 \mathrm{n}$. The depth to the top of the main SDRS increases away from the elevated Iceland-Greenland Ridge. These two observations indicate rapid exhaustion of the initially large diameter thermal anomaly down to the scale of the present day Icelandic anomaly.

\section{Planned geophysical investigations}

In addition to the work already underway, future work will include an additional seismic survey currently scheduled for 1996. This survey, called SIGMA (Seismic Investigations of the Greenland Margins), is a joint project between DLC and the Woods Hole Oceanographic Institution, USA, and is funded by both the U.S. National Science Foundation and DLC. This survey will expand the area already covered and will include the collection of refraction data using ocean bottom seismometers. The refraction information will constrain the seismic velocities and thus the crustal thickness and layering along the margin. Such observations form the basis for calculation of magmatic fluxes and mass balances, and for construction of crustal scale, thermo-mechanical models of the tectonic deformation that takes place during break-up.

\section{Tertiary magmatic rocks and extension structures}

Magmas contain a wealth of information on the nature of the parent materials and the temperature and pressure at the melting site, and may also contain evidence for the nature of the lithosphere which they have traversed to the site where they are presently found. Such magmatic rocks are also amenable to precise physical methods of dating, which allows a detailed chronological history to be established for large-scale events such as the impact of mantle plumes and continental separation.

For these reasons, DLC has decided to devote a major effort to a study of the magmatic rocks of East Greenland which were emplaced in connection with the birth of the North Atlantic Ocean, an event of major lithospheric deformation and new lithosphere formation, related to the present day Icelandic hot-spot (e.g. Brooks, 1973; Lawvers \& Müller, 1994). Furthermore, it has been decided to focus work on the basic and more primitive rocks as these are likely to yield most information on the asthenosphere and the deep levels of the lithosphere at the time of break-up. Such rocks now make up the intense dyke and sill complexes and gabbroic plutons along the coast, and the very extensive plateau lavas of the area between Kangerlussuaq and Scoresby Sund (Deer, 1976; Brooks \& Nielsen, 1982). A two-year programme has been planned for field work in East Greenland which will concentrate on the tectonism and igneous activity directly related to break-up.

Field operations in 1994 were supported by a helicopter stationed in Ammassaik. Mobilisation and demobilisation were effectuated using a Twin-Otter from Akureyri in Iceland to a natural landing strip at Nigertuluk (Fig. 5). Transport in the field was mainly by rubber boat or on foot.

Some regions along the east coast of Greenland have 


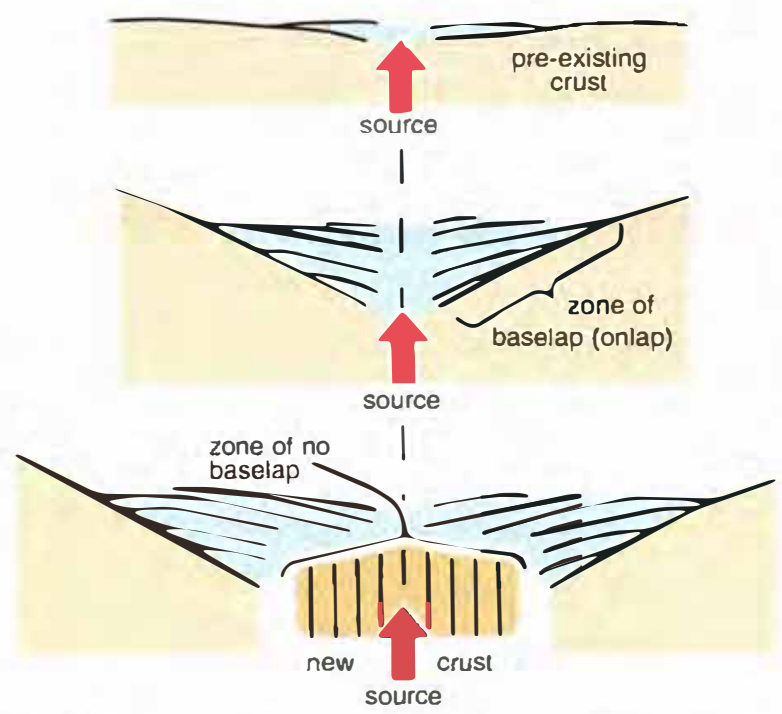

Fig. 3. A cartoon illustrating how the seaward dipping reflector sequences are formed. During the initial stage of continental break-up, large extrusive flows are emplaced on pre-existing crust. Subsequent thinning and extension of the crust rotate the sequences so that they dip towards the magmatic source. From Larsen \& Jakobsdóllir (1988).

previously been studied in detail and. together with the observations and material collected during the 1994 lield season. sufficient material and observattons are now available from south of Imilik (perhaps even as far south as the southern tip of Greenland) and up (o) als far north ats fi) $\mathrm{N}$ (Figs 1, 5) to permit modelling of the dynamics and malgmatism during continental break-up.

\section{South Greenland}

The southern $200 \mathrm{~km}$ part of the ealst coalst of Greenland (Fig. I) is characterised by deep and narrow tjords perpendicular to the continental margin. A few, but very thick, fjordparallel dykes are found along most of the fjords: the easswest orientation of tjords and dykes does not correspond to pre-existing structural trends in the Proterozoic termins of South Greenland. A restricted number of coast-parallel dykes are exposed on the outer coast: the ane of these dykes is unkinown, but they are thought to be related to a Lower Tertiary break-up event.

Simples of these doleritic dykes were collected for age determination and geochemical and petrological investigaltion. Three intersections between tjord-parallel and coastparallel dykes were observed, and in every calse the former are later. If these dykes are indeed Tertiary, their time of emplacement and their chemical composition will add important information to the investigation of the chronology and the distribution of malic magmals along the east coast of Greenland during continental break-up.

\section{Imilik-Tunilik region}

Coast-parallel dyke swarm of Easl Greenland. The coast parallel dyke swarm of East Greenland is a magnificent expression of the magmatism related 10 continental breakup (Fig. 4). It is exposed over several hundred kilometres of the coast (Wager \& Deer. 1938: Myers, 198()) and continental margin (Larsen, 1978) and may in terms of volume be comparable with the extensive platealu basalt areas in East Greenland. Transects of the coastal dyke swarm were made at Tuttilik, Tassiiliay and Imilik (southern part of the Kialiney district. Fig. 5). At all these locialities detailed measurements were made on up 10 f(0) dykes in each traverse, recording (where possible) thickness and orientiltion, kinemattic indicattors, petrological type and age relattionships. Approximately 5()() samples were taken for laborattory studies, which in the first instance will be directed towards characterising the various dyke generations encountered in the areal and comparing them with the findings of earlier work around Kangerlussuacy to the north. Noteworthy was the occurrence of very carly picritic dykes with grass-green clinopyroxene phenocrysts, and olivine-phyric picrite dykes with up to 20) \% $\mathrm{MgO}$, reminiscent of flows of the Lower Basalts in the Kanngerlussualy areal (Nielsen et al.. 1981).

Ultimately the investigations will be directed towards deducing the nature of the underlying lithosphere and asthenosphere in terms of chemistry, isotopic composition and previous history. In order to do this, it will be necessary to identily magmass which have risen from their site of melting undergoing minimal differentiation and interaction with the crust through which they have travelled to the surfiace. It may be that the best examples of such "primary" magmas may be restricted 10 microscopic inclusions in minerals, which have been protected by their host minerals from such interactions and also from subseyuent alteration by circulating heated ground waters. Such melt inclusions maly also have their original gals contents preserved, which would give valuable indications ats to the environmental effects or ore-forming capabilities of these magmas.

The const-parallel flexure of East Greenland. Evidence of major tectonic extension of the crust wass searched for during the field work. The classic description by Wager \& Deer (1938) of the East Greenland coastal dyke swarm emphasised the magmatic extension and collapse of the continental margin, but wass valgue about the tectonic component, although the need for some type of detachment between upper crustal brittle deformation and flow in an underlying ductile regime was recognised. Nielsen \& Brooks (1981) observed that many of the dykes were appalrantly intruded along a multitude of faults, each with minor displacement, but with considerable total diplacement. 


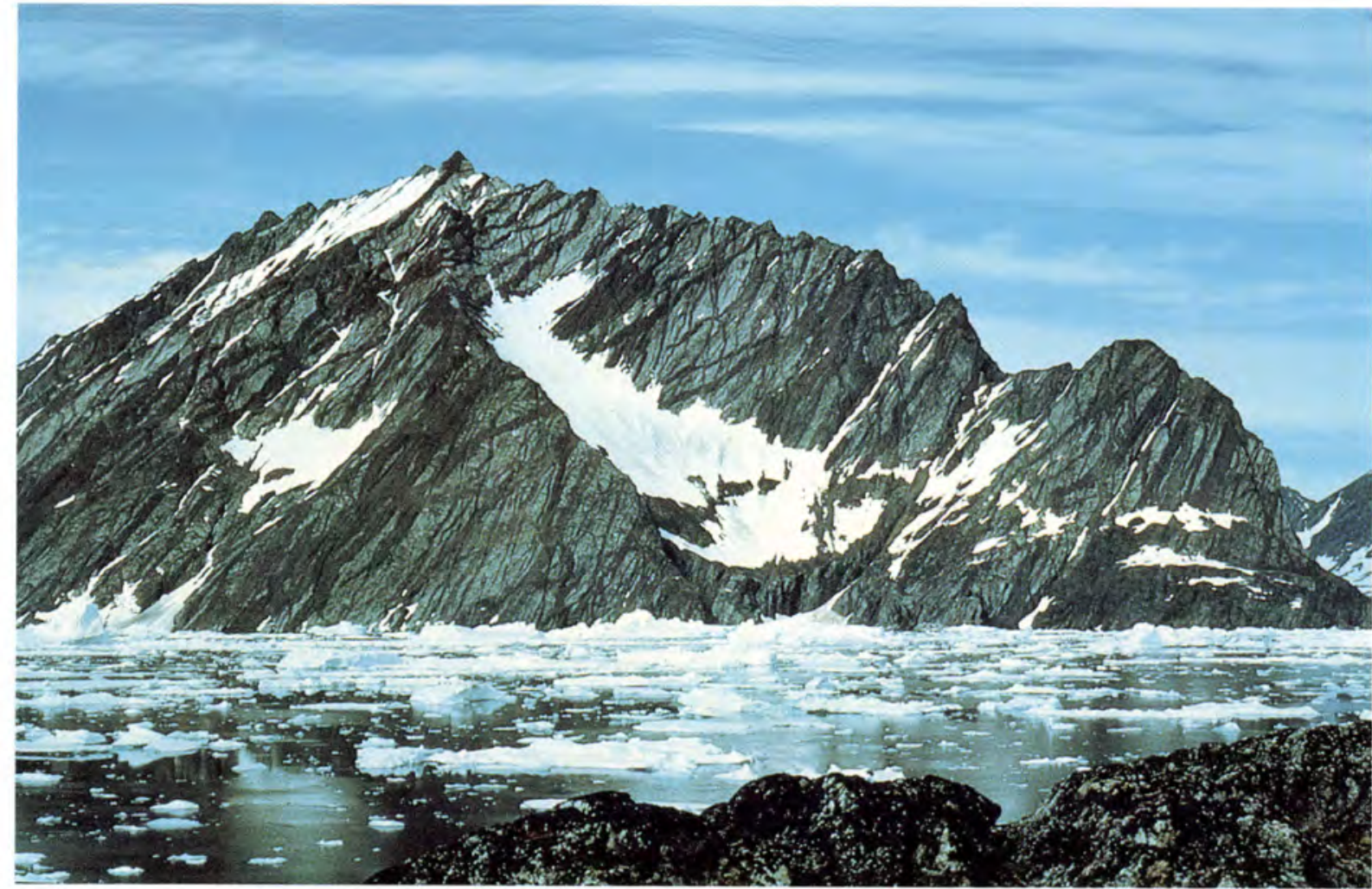

Fig. 4. The coast-parallel dyke swarm near Kap Gustav Holm seen from the south.

During the 1994 field work major faults were identified, some striking at a high angle to the coast, which may represent accommodation zones between segments of contrasting behaviour. Shearing of the dykes, with zones of mylonitisation and pseudotachylite formation, was ubiquitous. As at Kangerlussuaq, early, rotated, highly sheared dykes were identified, including picritic types and later dykes, which apparantly become more alkaline in composition and less rotated and deformed as they become younger

In the Imilik area, large gabbro bodies cut the main component of the dyke complex, indicating shallow-level magma-chamber formation at a late stage within this event. The youngest gabbros are only cut by a small number of dykes and are thus essentially post-dyking or flexuring, thereby confirming that gabbroic plutonism was a protracted event, not limited to the flexuring period as previously believed. Several generations of dyke intrusion were identified, but at present there is little information on the ages of intrusion or the actual length of time involved. A major dating project in collaboration with R. A. Duncan (Oregon State University, USA) is planned using ${ }^{40} \mathrm{Ar} /{ }^{39} \mathrm{Ar}$ techniques.

Imilik gabbro complex. The gabbros of Imilik located in the area of the coast-parallel flexure and dyke swarm were sampled with a view to identifying their parental magmas and deducing the mode of emplacement and their subsequent reaction with hydrothermal systems; the latter provides evidence of their thermal history (Nevle et al., 1994), which, in turn, is related to major vertical movements of the lithosphere.

Flexuring of the East Greenland lithosphere during continental margin collapse requires some type of accommodation at depth, which may be a faulted detachment, but may also be establishment of magma chambers. Gabbro bodies exposed intermittently along the East Greenland margin may be high-level representatives of much larger magma chambers present at depth along the entire margin.

Sulugssut complex. The Sulugssut complex (Fig. 5), first described by Brooks et al. (1989), appears to be a subvolcanic feeder to a now removed nephelinite volcano, located inland $(c .10 \mathrm{~km})$ of the main part of the coastal dyke swarm. It cuts an early swarm of very black dolerites, which, although standing sub-vertically, are tentatively correlated (on grounds of lithology) with the early, strongly rotated coastal dykes. If true, this conclusion will allow the precise dating of this generation as the coastal dykes are much more strongly altered, tectonised and probably overprinted by later events. A later swarm of 


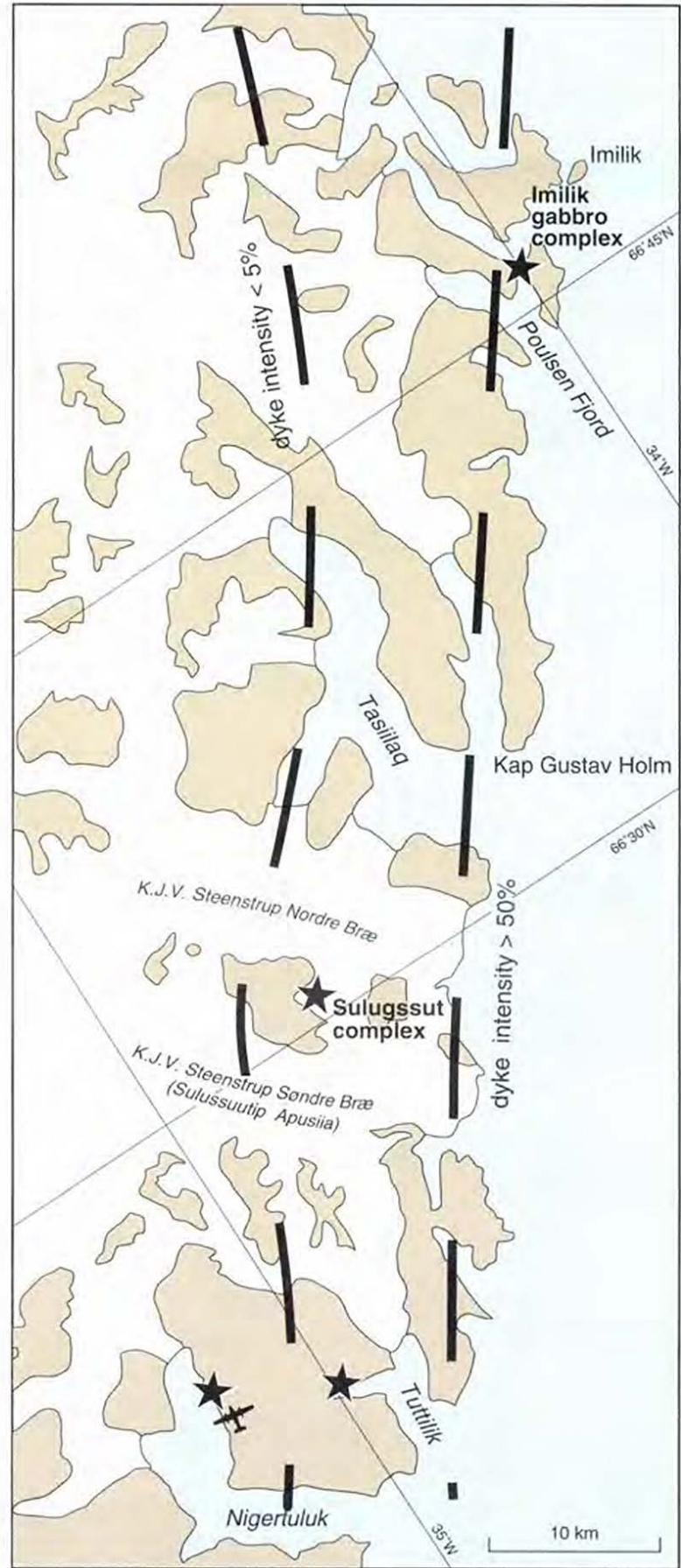

Fig. 5. Map of the main area covered by the Tertiary group in 1994. Camp sites (asterisks) and the landing strip at Nigertuluk are shown. Dyke intensity boundaries are approximate, after Niyers (1980).

brown dolerites cuts the Sulugssut complex, such that dating of samples from this area will enable a three point chronology to be erected for the succession of tectonic and magmatic events in the southern part of the province.
The Sulugssut complex and the dyke swarms in the Tuttilik areal (Fïg. 5) were found to contain carbonatites, rocks characteristic of regions of deep fatulting such als the Fast African continental rift (Woolley. 1989), but not previously recognised in this area. The presence of magmas of the nephelinite-carbonatite association, while of minor volumetric importance, provides eloquent evidence for such deep-faulting events also being present along the Fast Greenland volcanic rifted margin. Similar fealtures have not been reported from the conjugate margin. These alkatline rocks maly be relatively early as there is a suggestion that the earliest lavas on nearby Kap Gustav Holm atre of nephelinitic affinity.

Deep continental drilling. DI.C has made a proposal for deep drilling under the aluspices of the Coordinating Committee for Continental Drilling (International Lithosphere Program), in which it is proposed to probe the East Greenland coastal dyke swarm and its ansociated flexure at depth. This area represents probably the most advantageous site worldwide for investigation of a rifted continental margin. due to signilicant crustal attenuation accompanied by deep erosion. which means that drilling can commence at a much deeper stnuctural level (several kilometres) compared to other margins. A further argument for such a research drill hole is that it would complement the nearby offshore drilling programme, which has recently been accepted by the international Ocean Drilling Project as Leg 163. During summer 1994 cursory site investigations were made of suggested sites for such onshore drilling and one apparantly well suited site wass identilied adjacent to Kap Gustav Holm (Fig. 5). This will he investigated in more detail in 1995 or 1996.

\section{Iameson Leind}

A two man team worked in the Jameson Land area (70) N: Fig. 1) in order to gather representative material from Lower Tertiary dykes and sills for petrological and geochemical characterisation. This study is a follow-up of the seismic study by l.arsen \& Marcussen (1992) and will investigate the role of sills in tlood basalt volcanism in a basinal selting. It is also intended to bridge the gap between the llood basalts exposed to the south of Jameson L.and (Larsen et al., 1989) and those 206) km farther north (Upton et al.. 1984; Thirlwall et (al., 1994).

In northern Jameson Land major sills occupy two different levels in the Mesozoic sedimentary sequence, ats reported by Birkelund \& Perch-Nielsen (1969). A single basaltic sill 4()-6() $\mathrm{m}$ thick intruded at the lower level, while at the upper level one or more sills up to 30 m thick, as well as a number of much thinner, basaltic todionitic sills $(1-5 \mathrm{~m})$ are found. Two distinct rock types were encountered, one of which is characterised by numerous tabular feldspar 


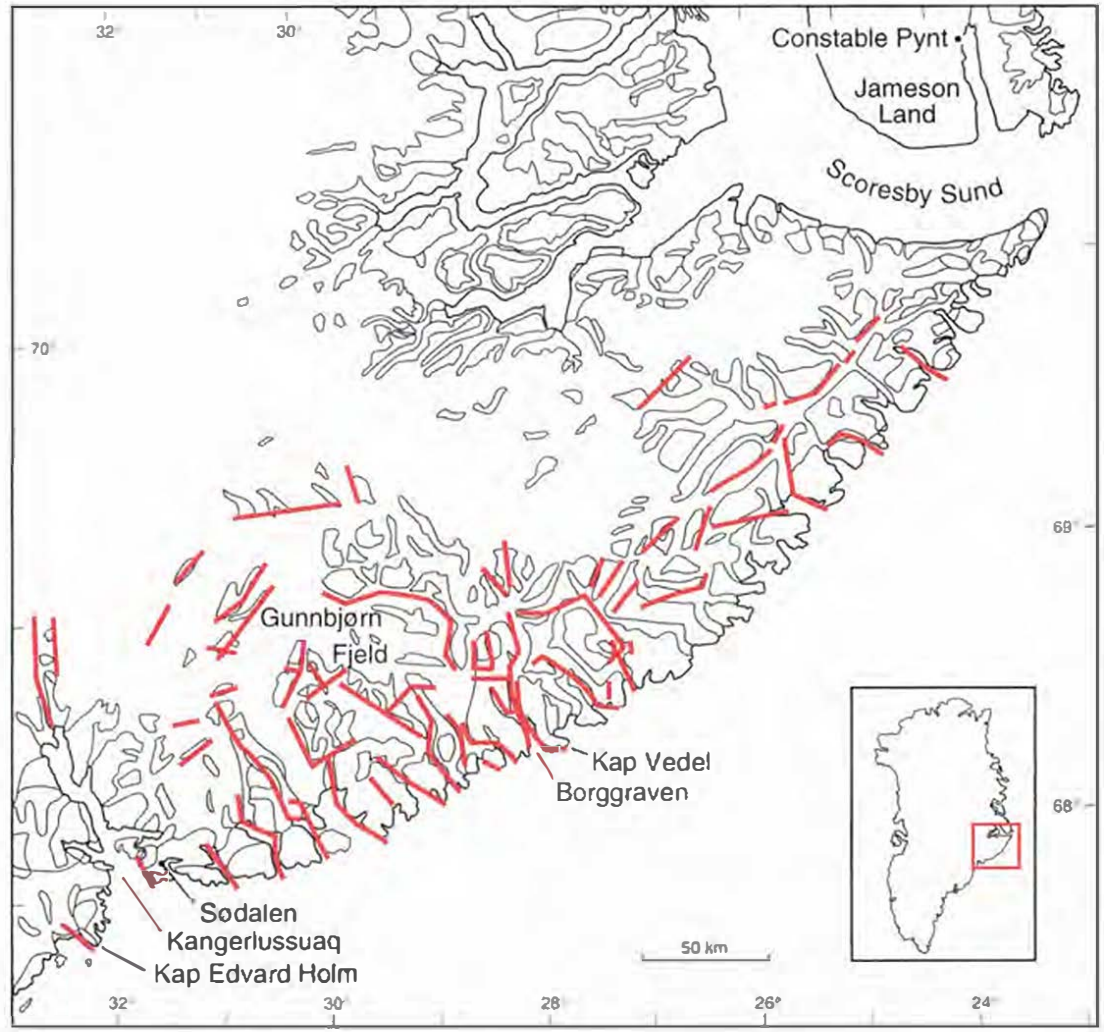

Fig. 6. East Greenland between Kingerlussualy and Scoresby Sund. Stereo-photographed sections are shown in red. phenocrysts up to $6 \mathrm{~cm}$ across.

In central and southern Jameson Land many dykes of aphyric dolerite were sampled, but sills are sparse. The plagioclase-phyric 'Fame $\theta$ ' porphyry (Noe-Nygalard. 1976) may be related to the porphyritic sills to the north. A short visit (o) Liverpool Land resulted in finds of a suite of lamprophyre dykes characterised by abundant biotite and amphibole phenocrysts: their age is not well constrained but they are likely to provide important clues to the thermal and chemical development of the source region.

\section{Stereo-photography along the continental margin of East Greenland, $\left.66^{\circ} \mathrm{N}-71\right)^{\circ} \mathrm{N}$}

The Lower Tertiary flood bassalts along the eass coast of Greenland between Kangerlussuay and Scoresby Sund are excellently exposed. but inaccessible without extensive use of airborne support. The geology of the magmatic rocks is fairly well known in the Kangerlussuat region (Brooks \& Nielsen. 1982: Nielsen (" al.. 1981) and in the Scoreshy Sund region (Larsen et al. 1989). However, the intervening region which is roughly 25() $\mathrm{km}$ by $I()() \mathrm{km}$ in size and rises $(0$ almost $4(0)(0) \mathrm{m}$ altifude. is poorly known except for a few studies of intrusions and reconnaissance studies of the basalts. Thus the overall stratigraphy, lateral structure, total stratigraphic thickness. magma volumes and chemical variation in time and space of the East Greenland flood basalt province are imperlectly known. As this information is of crucial importance for the overall study of the East Greenland volcanic margin DLC has initialted a special investigation of this area.

Due to the difficulty of access. poor map coverage, and faulting along the coastline which renders the establishment of a stratigraphic record difficult, the area between Kangerlussulay and Scoreshy Sund was surveyed in (9) 4 by airborne steren-photography. The development of multimodel photogrammetry as an advanced tool for geological and structural studies has opened up new possibilities for this type of study. The method uses colour diapositives taken with ordinary hand-held small-fiame cameras (o) provide stereographic coverage of long sections of terrain, and it enables quantitative geological measurements and compilations to be carried out on inaccessible mountain walls (Dueholm, 1992: Pedersen \& Dueholm. 1992).

\section{The phorographic operation}

Systematic airborne stereo-photography of the laval platteau and the coastal dyke swarm wals carried out during 12 days in the beginning of August 1994, with Constable Pynt in Jameson Land as operational base and the airstrip in Sudalen near Kangerlussuary as back-up and refueling sta- 

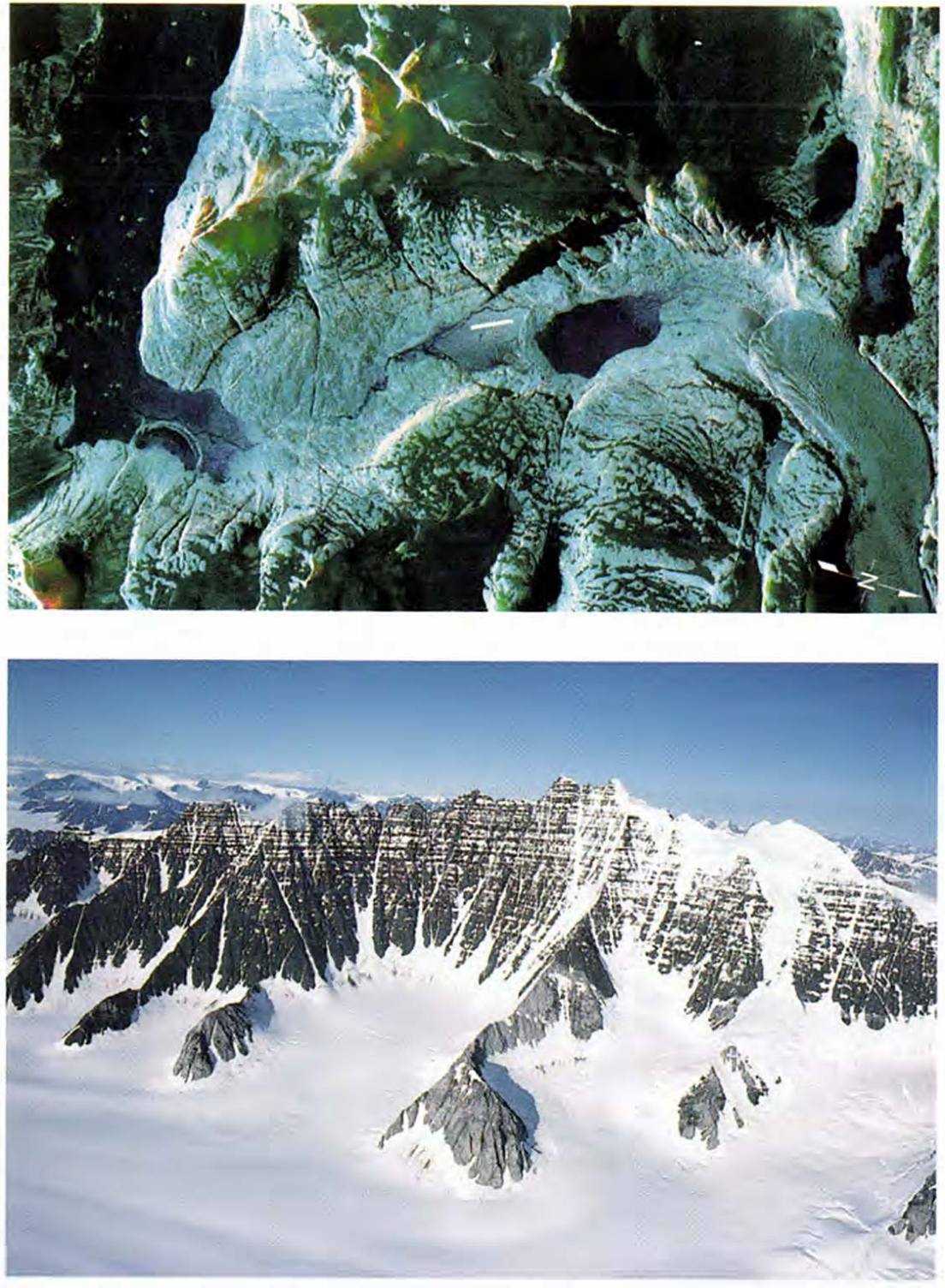

Fig. 7. The East Greenland Tertiary basalt province is the most inacessible in Greenland. Only the raised beach-terraces in Sodalen offer a possible landing strip for STOL aircralft. A SAR (= synthetic aperture radar) image of the Sordalen area wals obtained during the field season by 3 radar reflectors. These were deployed in co-operation with the Danish Centre for Remote Sensing to evaluate the use of $S A R$ imaging for geological purposes in this type of terrain. The data were acquired and processed by the Danish Centre for Remote Sensing. Electromagnetics Institute. Technical University of Denmark.

Fig. 8. Lower Tertiary plateau balsalts cut by numerous joints and minor faults. The light grey rocks in the foreground are syenites of the Borgtinderne intrusion. Multi-model photogrammetry allows a geological analy'sis of the structure and stratigraphy of the laval platealu and the relation to later plutonic activity. tion (Figs 6, 7). Location of profiles was based on reconnaissance studies carried out on $1: 15()(0)()$ vertical aerial photographs in the analytical plotter at the Institute of Surveying and Photogrammetry (ISP). Technical University of Denmark.

The aircraft used was a Twin-Otter equipped with windows that could be opened during photography. and with ferry lanks giving 7 hours endurance. Air speed during photography was typically around $2(0) \mathrm{km}$ per hour. Many sections were photographed both in overview and in detail. and the detailed photographic series were often taken in two or more panels above cach other. The highest mountain in Greenland - Gunnbjorn Fjeld with a height of 37()() $\mathrm{m}$ was taken in four stacked panels.

Altogether, 16()() $\mathrm{km}$ of mountain sides were stereo- photographed (Fig. 6). The photographed sections in the lava platcau were preferentially oriented perpendicular to the coast along the major glaciers and define a number of major cross-sections from the coast and inland. allowing a three-dimensional study of the stratigraphy and structure of the lava plateat and continental margin. A number of photographed sections through the coastal dyke swarm between Kap Edvard Holm near $68^{\circ} \mathrm{N}$ and Kangertittivatsiay near $66^{\circ} \mathrm{N}$ were similarly oriented, i.e. at right angles to the strike of the dyke swarm.

\section{Results}

About 6()() colour diapositives are now available for multi-model photogrammetry. A test section consisting of 70 
stereo models has been set up in the Kern DSR 15 analytical plotter at ISP. The section runs for $c .40 \mathrm{~km}$ from Kap Vedel north-west along the east side of Vedel Fjord and the glacier Borggraven (Figs 6, 8). It contains a wealth of quantifiable information about the volcanic stratigraphy, fault and fracture systems, and dyke distribution. The volcanic pile shows a very varied lithology with a number of distinctly different units and indications of possible eruption sites. With the aid of this section, and several more to come, a stratigraphic reference frame for the whole area will be established and a detailed sampling plan for the helicopter-supported field work on the lavas and dykes in 1995 can be worked out. The goal for the field work is systematic flow-to-flow sampling in a number of well-defined composite profiles in the poorly known area. With the stratigraphic reference frame in hand, the best possibilities of ensuring stratigraphic completeness and sufficient areal coverage and lateral control of our work will be achieved.

Acknowledgements. The seismic investigations offshore SouthEast Greenland were successfully carried out with the invaluable assistance of personnel at GECO-Prakla in the planning and execution of the 1994 survey and the crew on board M/V GECO Echo. The work was carried out in co-operation with BIRPS (British Institutions for Reflection Profiling Seismology) which collected data between the Shetland Islands and Iceland using the same ship. In addition, Minik Rosing, Jesper Fallesen and Hans Thybo (University of Copenhagen) were responsible for setting up the seismic stations on land.

The 1994 field operation in areas to the north of Ammassalik was carried out with efficient support from Greenlandair A/S (Nuuk, Greenland - Bell 212 helicopter), Flugfélag Nordurlands $\mathrm{H} / \mathrm{F}$ (Akureyri, Iceland - Twin Otter) and Djúpbáturrin $\mathrm{H} / \mathrm{F}$ (Isafjördur, Iceland - ship). The skill and professionalism of the flight crews was decisive for the success of the field operations.

Finally, T. Hauge Andersson of Danish Polar Centre is thanked for his invaluable help in the planning and execution of the field work in the Jameson Land area, and GGU is thanked for making possible the collection of dyke samples in southernmost East Greenland.

Appendix. The 1994 field parties were:

Imilik-Tuttilik region: Stefan Bernstein, DLC, Copenhagen; Dennis K. Bird, Stanford University, California, USA; C.K. Brooks, Geological Institute, University of Copenhagen; Karen Hanghøj, DLC, Copenhagen; Jeff Karson, Duke University, Durham, North Carolina, USA; Martin Bromann Klausen, Nordic Volcanological Institute, Reykjavik, Iceland; Ariel Kleckner, Stanford University, USA; Troels F. D. Nielsen, DLC, Copenhagen; Christian Tegner, DLC, Copenhagen.

Jameson Land: Niels Hald, Geological Museum, University of Copenhagen; Jesper Kofoed, Geological Institute, University of Copenhagen.

Airborne stereo-photography: Neil Irvine, Carnegie Institution of Washington, USA; Lotte Melchior Larsen, Geological Survey of Greenland, Copenhagen; Asger Ken Pedersen, Geological Museum, University of Copenhagen; Margrethe Watt, Rønne, Denmark; Stuart Watt, Geological Survey of Greenland, Copenhagen.

\section{References}

Birkelund, T. \& Perch-Nielsen, K. 1969: Field observations in Upper Palaeozoic and Mesozoic sediments of Scoresby Land and Jameson Land. Rapp. Grønlands geol. Unders. 21, 21-33.

Brooks, C. K. 1973: Rifting and doming in southem East Greenland. Nature, Phys. Sci. 244, 23-25.

Brooks, C. K. \& Nielsen, T. F. D. 1982: The Phanerozoic development of the Kangerdlugssuaq area, East Greenland. Meddr Gronland, Geosci. 9, $30 \mathrm{pp}$.

Brooks, C. K., Dawes, P. R. \& Soper, N. J. 1989: The Sulugssut intrusive complex: a new Tertiary alkaline centre in East Greenland. Rapp. Grønlands geol. Unders. 146, 95-100.

Coffin, M. F. \& Eldholm, O. 1992: Volcanism and continental break-up: a global compilation of large igneous provinces. In Storey, B. C., Alabaster, T. \& Pankhurst, R. J. (ed.) Magmatism and the causes of continental break-up. Spec. Publ. geol. Soc. Lond 68, 17-30.

Coffin, M. F. \& Eldholm, O. 1993: Scratching the surface: estimating dimensions of large igneous provinces. Geology 21, 515-518.

Dahl-Jensen, T., Larsen, H. C., Hopper, J. R., Rosing, M. T., Fallesen, J. \& Thybo, H. 1994: Extent of seaward dipping reflector sequences at the SE Greenland volcanic rifted margin: a new deep seismic survey. EOS 75, 591 only.

Deer, W. A. 1976: Tertiary igneous rocks between Scoresby Sund and Kap Gustav Holm, East Greenland. In Escher, A. \& Watt, W. S. (ed.) Geology of Greenland, 405-429. Copenhagen: Grønlands Geologiske Undersøgelse.

Dueholm, K. S. 1992: Geologic photogrammetry using standard small-frame cameras. Rapp. Grønlands geol. Unders. 156, $7-17$.

Hinz, K., 1981: A hypothesis on terrestrial catastrophes: wedges of very thick oceanward dipping layers beneath passive continental margins; their origin and paleoenvironmental significance. Geologisches Jahrbuch 2, 3-28.

Holbrook, W. S. \& Keleman, P. B. 1993: Large igneous provinces on the US Atlantic margin and implications for magmatism during continental breakup. Nature 364, 433-436.

Hopper, J. R., Mutter, J. C., Larson, R. L., Mutter, C. Z. \& Northwest Australia Study Group 1992: Magmatism and rift margin evolution: evidence from northwest Australia. Geology 20, 853-857.

Larsen, H. C. 1978: Offshore continuation of the East Greenland dyke swarm and North Atlantic Ocean formation. $\mathrm{Na}$ ture 274, 220-223.

Larsen, H. C. 1990: The East Greenland shelf. In Grantz, A., Johnson, L. \& Sweeny, J. F. (ed.) The Arctic Ocean region. The Geology of North America L-12, 185-210. Boulder, Colorado: Geological Society of America.

Larsen, H. C. \& Jakobsdóttir, S. J. 1988: Distribution, crustal properties and significance of seawards-dipping sub-basement reflectors off E Greenland. In Morton, A. C. \& Parson, L. M. (ed.) Early Tertiary volcanism and the opening of the NE Atlantic. Spec. Publ. geol. Soc Lond. 39, 95-114.

Larsen, H. C. \& Marcussen, C. 1992: Sill intrusion, flood basalt emplacement and deep crustal structures of the Scoresby Sund region, East Greenland. In Storey, B. C., Alabaster, T. \& Pankhurst, R. J. (ed.) Magmatism and the causes of continental break-up. Spec. Publ. geol. Soc. Lond. 68, 365-386. 
Larsen, L. M., Watt, W. S. \& Watt, M. 1989: Geology and petrology of the Lower Tertiary plateau basalts of the Scoresby Sund region, East Greenland. Bull. Gronlands geol. Unders. 157, $164 \mathrm{pp}$.

Lawvers, L. A. \& Müller, R. D, 1994: Iceland hotspot track. Geology 22, 311-314.

McKenzie, D. \& Bickle, M. J. 1988: The volume and composition of melt generated by extension of the lithosphere. J. Petrol. 29, 625-679.

Mutter, J. C., Buck, W. R. \& Zehnder, C. M. 1988: Convective partial melting 1. A model for the formation of thick basaltic sequences during the initiation of spreading. J. Geophys. Res. 93, 1031-1048.

Myers, J. 1980: Structure of the coastal dyke swarm and associated plutonic intrusions of East Greenland. Earth Planet. Sci. Lett. 46, 407-418.

Nevle, R. J., Brandriss, M. E., Bird, D. K., McWilliams, M. O. \& O'Niel, J. R. 1994: Tertiary plutons monitor climate change in East Greenland. Geology 22, 775-778.

Nielsen, T. F. D. \& Brooks, C. K. 1981: The E Greenland rifted continental margin: an examination of the coastal flexure. J. geol. Soc. Lond. $138,559-568$.

Nielsen, T. F. D., Soper, N. J., Brooks, C. K., Faller, A. M., Higgins, A. C. \& Matthews, D. W. 1981: The pre-basaltic sediments and the Lower Basalts at Kangerdlugssuaq, East Greenland: their stratigraphy, lithology, palaeomagnetism and petrology. Meddr Gronland, Geosci. 6, $28 \mathrm{pp}$.

Noe-Nygaard, A. 1976: Tertiary igneous rocks between Shannon and Scoresby Sund, East Greenland. In Escher, A.\& Watt, W. S. (ed.) Geology of Greenland, 386-402. Copenhagen: Grønlands Geologiske Undersøgelse.
Pedersen, A. K. \& Dueholm, K. S. 1992: New methods for the geological analysis of Tertiary volcanic formations on Nuussuaq and Disko, central West Greenland, using multi-model photogrammetry. Rapp. Gronlands geol. Unders. 156, 19-34.

Thirlwall, M. F., Upton, B. G. J. \& Jenkins, C. 1994: Interaction between continental lithosphere and the Iceland plume - Sr$\mathrm{Nd}-\mathrm{Pb}$ isotope geochemistry of Tertiary basalts, NE Greenland. J. Petrol. 35, 839-879.

Upton, B. G. J., Emeleus, C. H. \& Beckinsale, R. D. 1984: Petrology of the northern East Greenland Tertiary flood basalts: Evidense from Hold with Hope and Wollastone Forland. $J$. Petrol. 25, 151-184.

Wager, L. R. \& Deer, W. A. 1938: A dyke swarm and crustal flexure in East Greenland. Geol. Mag. 75, 49-56.

Woolley, A. R. 1989: The spatial and temporal distribution of carbonatites. In Bell, K. (ed.) Carbonatites: genesis and evolution, 15-37. London: Unwin Hyman.

T. D.-J. \& T. F. D. N., Geological Survey of Denmark and Greenland, Copenhagen. Present address: Danish Lithosphere Centre, Øster Voldgade 10, DK-1350 Copenhagen K, Denmark H. C. L.\& J. R. H., Danish Lithosphere Centre, Øster Voldgade J0, DK-1350 Copenhagen $K$, Denmark

C. K. B., Geologisk Institut, Øster Voldgade 10, DK-1350 Copenhagen $K$, Denmark

A. K. P., Geologisk Museum, Øster Voldgade 5-7, DK-I350 Copenhagen $K$, Denmark (see also appendix) 

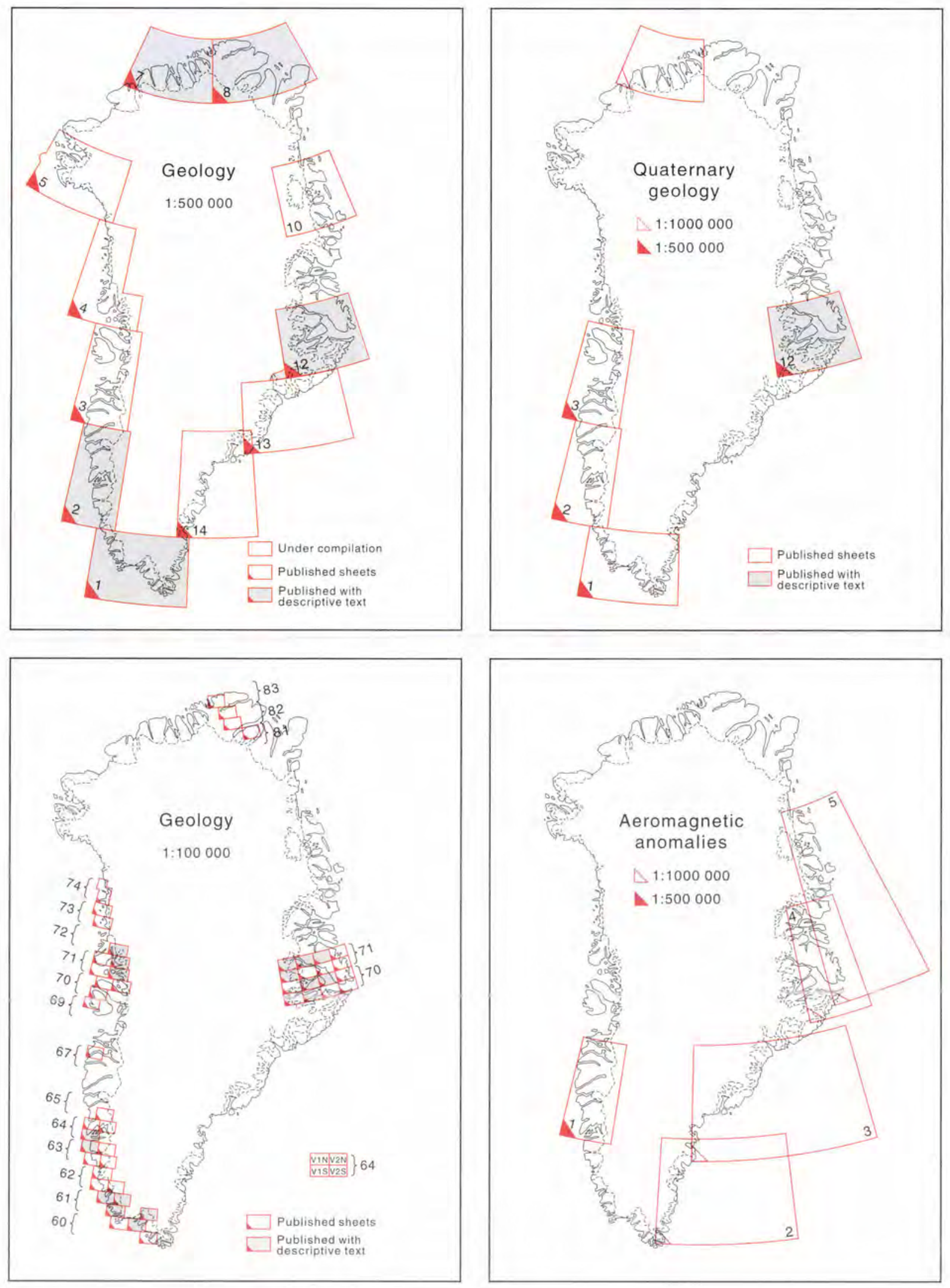